雖「デフテリア菌が液狀培地二發育シテ强力 ナル毒素ヨ形成スル際二必ラズ産生セラル、 モノナラン。此色素ト Coulter 及ビ Stone が 「デフテリア原毒素ョリ見出シタルPorphyrins トノ異同二就テハ近キ機會二論ズ可シ。

3）粉末狀精製 Toxoid 八非常二强力ナル
免疫元性 ヨ有スルニ拘ラ ズ抗毒血清トノ間二 Floculation $\exists$ 起ス性能 7 缺如スル事ハ極メテ 興味深キ事實ナり。

4) 粉末狀精製 Toxoid $\exists$ リ水蒸氣蒸餾 $=$ ヨリテ $118-120^{\circ} \mathrm{C}=$ 於テ融點 $\exists$ 有スル黃色 結晶 $\ni$ 得タリ。

\title{
新交獻 抄錄
}

\section{物質代謝ノ表面律二就テ}

Otto Kestner

Pfluigers Arch. f. Ges. Physiol. 234 Band, 3 Heft, 290, 1934.

Bergman ニョリ初メテ唱ヘラレタ物質代 謝ノ表面律郎千物質代謝入動物ノ體表面積二 比例スルト云フ假定が果シテ正シイカ否カ二 就テ論ジ.次ノ結論二到達シティル。

小動物ノ活潑ナル物質代謝ハソノ體表面積 ト八關係が無イ。小動物殊二幼苦ナル動物二 於テ八臟器ノ酸素消費量八大動物殊二老年, 動物ヨリ大キ1。動物が若ケレバ若イ程呼吸 シテキル生活原形資ノ量入大デアル。（守山）

\section{筋肉中ノ結合或八游離}

\section{Kalium}

E. Ernst u. J. Fricker

Pflügers Arch. f. Ges. Physiol. 234

Band, 3 Heft, 360, 1934.

氷冷セシメタ蛙カラ筋肉 凍結セシメタル後粉末狀二粉碎ス。此ノ粉末 $\Rightarrow \mathrm{O}^{\circ} \mathrm{C}=$ 於テ蒸餾水卜混 $シ$ Aceton デ”蛋白 質ヨ沈澱セシムル。然ル後ソノ蛋白貿及ビ滤 液中, $\mathrm{K} \ni$ 別々 於テ熱强值 興へタモ/及ビ刺戟 セシメテ置イタモノ二就テ實驗ス。

休息シテキタ筋肉，濾液八總 $K$ 量 $1 / 5-1 / 3$ ヨ有スルノミデアルニ拘ラズ. 豫メ刺戟 $\ni$ 興 ヘタ筋肉, 滤液ヘソノ $11 / 2-3$ 倍量ノ K 7 含
有スル。郎チ intakt，筋肉中 $=ヘ \mathrm{~K}$ ，大部分 八不參透性ノ形デ含有サレテキルガ. 刺载或 八熱强直 7 與へルト疹透性ノK八著シク增大 スル。（守山）

\section{Vitamin $B_{2}$ トシテノ Flavin}

\section{及ヒ Flavoprotein}

Paul György, R. Kuhn u. T. WagnerJauregg. Zeit. f. Physiol. Chemie, Band. 223, 241, 1934.

Flavin ト八生物體中二含有苠レ.酸化還元 二關係 $\ni$ 有スル綠色䖝光 $\ni$ 發スル色素デア ル。此ノ色素八䏦臟ヤ酵母中デハ蛋白資卜結 合シテ. 不透性ノ大キナ分子量 7 有スル Flavoprotein トシテ存在スル。 Warburg u. Christian ニョリ發見サレタ gerbe Ferment ト八明カ二此, Flavoprotein デアル。

著者等八動物，發育促進作用 $ヨ$ リ此， Flavin 及ビ Flavoprotein, Vitamin $\mathbf{B}_{2}$ 作 用ヨ磪メテキル。Flavin モ Flavoprotein モ 同程度, Vitamin $\mathrm{B}_{\mathbf{2}}$ 作用 $\exists$ 有ス。郎 $=$ Flavin フVitamin $B_{2}$ デアル。（守山）

\section{Peptidase 作用二及ボ ス影留 二於テノ $\mathrm{Zn}$ ト $\mathrm{HCN}$ ノ 拮抗作用二就于 \\ 'K. Linderström-Lang.}

Zeit. f. Physiol. Chemie, Band, 224, $121,1934$.

Proteinase ト金筤トノ關係ニ就テハ今日デ 
八可ナリョク知ラレテキルが. Protease 八第 2 ノ大キナ Gruppe タル Peptidase $=ッ 1$ テハアマリ調ベラレテキナイ。

著者》Zn-Acetat, $\mathrm{HCN}$ 及ビソソ混合物 Darmpeptidase 二對スル作用二就テ研究シタ。 Substrat トシテハAlanylglycin $ヨ$ 用ヒタ。

$\mathrm{Zn}$ 八 $3.10^{-3} \mathrm{~N} ヨ$ リ以下デアルト Peptidase ノ作用 $\exists$ 促進セシムル。然シソレ以上, 濃度デハ抑制的二作用スル。約 $0.8 .10^{-4}$ $4.10^{-4} \mathrm{~N}$ 八濃度デ. ソノ促進作用が最大デア ル。 HCN ，何レノ濃度二於テモ阻止スルバ カリデアル。

$\mathrm{Zn}$ ，ノカ、ル促進作用八酳素作用二有害ナ ル末知ノ物質卜結合シテ.ソノ有害作用 7 奪 フコトニ基クモノト思ハレル。

$\mathrm{HCN}$ ト $\mathrm{Zn} ト \exists$ 同時二作用七シムル時八 複雜ナル關係が見ラレル。之N $\mathrm{Zn}$ ガ $\mathrm{HCN}$ 卜化合シテオ互ヒニソノ有害作用 $\Rightarrow$ 抑止スル コト. 及ビ $\mathrm{Zn}$ ，濃度小ナル時，促進作用等 ノ第デアル。（守山）

\section{Brenztraubensäure $\exists$ J Aceton 體形成 $\boldsymbol{\nu}$ 化學的 過程及ヒ生理的 條件二就テ}

Ernö Annau.

Zeit. f. Physiol. Chemie, Band. 224, 3 u. 4. Heft, 141, 1934,

含水炭素. 大部分, Amino 酸。及ビ脂肪 ノ酸化分解二際シテ Brenztraubensäure ガ生 ズルト云フコトハ周知ノ事實デアル。從ッテ 此 酸八酸化過程二於テ 中心的位置 $\ni$ 占メテ キル。

此入研究 、 Brenztraubensäure カラ Aceton 體が形成サレル過程・詳細ニ知ランが第二行 ヘレタ。著者ハ先ヅ Brenztraubensäure， 生理的酸化, Modellversuch トンテ. 之二 $\mathrm{H}_{2} \mathrm{O}_{2}$ ヨ作用セシメ少量ナがラ Aceton 體ノ 形成サレルヨ認メ得タ。面白イコトニン之二 $\mathrm{NH}_{4} \mathrm{OH} \ni$ 加へルト著シクAceton 體ノ形成

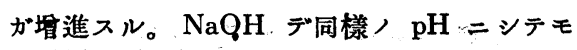
更二Aceton 體形成ノ增進が認メラレナイ所 ヨ見ルト。此ノ作用八 $\mathrm{NH}_{4} \mathrm{OH}=$ 特有ナモ ノデアリ。 $\mathrm{pH}$ ，孌化ノ爲デハ無イ。

之八恐ラ刃 $\mathrm{NH}_{4} \mathrm{OH}$ が Brenztraubensäure , Polymerisierung $\ni$ 促スコトニ基クモノデ アラウ。理論的ニ Brenztraubensäure 八酸化 メ.ソノ. Polymerisierung $=\Xi$ リ容易二行八 レ得ル。又此ノント八生理的二モ證明シ得ル。 師 $\neq$ Polymere Produkte $\Rightarrow$ in vitro $=$ 肝臟 强二加ヘル時ハPolymerisierung. ヨ起シテキ ナイ Brenztraubensäure $ヨ$ 加へタ時ヨリモ3 -4 倍多量, Aceton 體が生ズル。

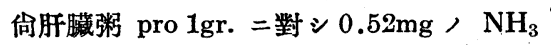
，加へル時二モ Aceton 形成ヘ4-5 倍二增 進スル。故 $=\mathrm{NH}_{3}$ 八 Brenztraubensäure , Polymerisierung $\exists$ 促スコトニョリAcetón. 體形成 7 增進セシムルモノト思ハレル。 $\mathrm{NH}_{3}$ 八獨り Brenztraubensäure カラノAceton 體形成 $\ni$ 促進スルノミナラズ。訮臟ノ Brenztraubensäure 形成りレ自身 $尹 モ$ 促進スルモ, デアル、從ッテ $\mathrm{NH}_{3}$ ハ二樣ノ意味デ Ketogen タリ得ル。郎チBrenztraubensäure ノ形成 $\exists$ 助長スル事ト. 之 7 更二 Aceton 體二迄變化 セシムル事トデアル。

Brenztraubensäure カラノ Aceton 體形成 ニ八 $\mathrm{NH}_{3}$ ガカクノ如キ重大ナル役割 7 演ズ ルノデアルが. 脂肪酸カラ Ketogenese = 八全ク無關係デアル。

肝䑏が Brenztraubensäure カラ Aceton 體 ヨ形成スル能力ハソノ遊離 $\mathrm{NH}_{3}$ ，含有量二 左右サレルコト入上述ノ通リデアルが. 佾ソ ノ他ニソ 八榮養狀熊郎 $千$ Glykogen 含有量卜 モ關係スル。饑解ノ初期二於テハAceton 體 形成八增進スルケレドモ。饑解狀態が長ク續 クト却ッテ・ソノ形成八減少スル。之ハ恐ラ 》長時間ノ饑諓ノ後二へAcetessigsäure 7 更. 二分解スル能力が增大スル雲二 Aceton 體ハ 蓄積が認メラレヌニ基クモノデアラウ。

(守山) 


\section{結晶 Trypsin J Inactivation}

M. Kunitz and J. H. Northrop.

Jour. of General Physiol. Vol. 17,

No. 4, 591, 1934.

純蛋白筫デアル所ノ結晶性 trypsin 及ビ溫度ヨ戀へタ際二起ル inactivation =就 テ研究ンタ。

Inactivation 八可逆的ノコトモ不可逆的ノ コトモアル。可逆的 inactivation 八蛋白質 可逆的 denaturation $\exists$ 件フ。denaturation ヨ受ケタ蛋白貿八自然狀態ニアル 活性蛋白質 ト本衡狀態 ニアルガ. ソ，本衡八溫度或八 Alkali 性, 增加卜共= denatured form 八方 二移神。

$\mathrm{pH}$ ガ 8.0 カラ 12.0 二堽大スル二隨と trypsin 活性度が減少スルノ八此ノ不可逆的 denaturation $\ni$ 受ヶタ蛋白質生成二因ル活性 醭素, 隇少二基》。

高溫或八 Alkali 性二於テ，酵素活性，消失 八頗ル急速度二行ハレ. 唯暫時ノ間ダケ完全 二可逆的デアル。而シテ時間 次不可逆的ニナル。

$\mathrm{pH} 2.0 \exists$ リ酸性側二於テ trypsin 蛋白八 不活性型二變化シ.熱 $=$ ヨリ不可逆的 denaturation $ヨ$ 受ケル。此ノ反隹ハ一次反隼デアリ 酸性度が堵ス二從ヒソ, 反應速度モ增大ス。

pH 2.0 ヨリ 9.0 マデノ間二於テハ trypsin 蛋白八徐々 二水解サレル。此，反應八二次反 應デ. pH 10.0 マデッ alkali 性が管スト共 二反隹速度モ管大スルが更 $=\mathrm{pH}$ ，增加スル 時八反應速度ハ却ツテ減少ス。此ノ二反應ノ 粘果トシテ $\mathrm{pH} 2.3$ ガ最大安定度ノ點デアル。 $\mathrm{pH} 13.0$ カラ Alkali 側二於テ八强酸性， 場合卜同椂二不活性蛋白が生ズ。此, 反應八 一次反應デ alkali 性, 增大卜共二速度增進が 見ラレル。

pH 9.0 カラ 12.0 マデノ間デハ一種ノ水 解が起り不活性蛋白が出來ル。此ノ過程ハ一 次反應卜二次反應トノ和デ表シ得ル。 pH 13.0 ヨy更二 alkali 性ニナルト水解
度ハ娍少スル。從ツテ $\mathrm{pH} 13.0$ 附近二於テ inactivation が最小デアル第二ノ點が存在ス ル。要スルニ是等ノ佟件ノ下デッtrypsin 活 性度, 減少八 trypsin 蛋白, 減少二比例スル モノデアル。（守山）

\section{試驗管内ニ於ヶル Spirochäta 及ピ Trypanosoma $=$ 對スル 藥纃ノ結合}

E. Singer, J. Kotrba u. V. Fischl.

Z. Hyg. 116. Bd. 2. Heft. 1934.

Spirochäta 及ビ Trypanosoma =感染シタ 「マウス」ヨ特殊作用ノアル 砒妻及ビ,金製劑デ 處置シタ場合二八是等ノSpir. 及ビ Tryp. 八 多量ノ砒素及ビ金ヨ含有スルコトヨ前報デ報 告シタ。化學治療劑/作用機序 7 更二䛃明ス ルタメニ八試騟管內デハカ、ル䒚群ノ溶液二 對シ微生物がイカナル態度 $ヨ$ トルカヨ檢查ス ル必要がアル。

Nagana Prowazek 或八歐洲再歸熱习感染 サセタ「マウス」カラ感染極期前二探血シタモ , ヨ試驗材料トシ砒素八 colorimetrisch $=$ 金 八 spektrographisch 二檢査シタ。

化學治療劑, 間接作用方法 7 認ムルタメニ 八主要ナ理由トナッテキル所ノ5 價ノ砒素劑 及ビ Thiogold 化合物八試驗管內デ八微生物 二對シテ作用シナイトイフ周知ノ事賽 ヨ考虑 二入レ. 且肝臟 $\ni$ 加ヘルコトニョッテ Atoxyl 溶液が活動的ニナルトイフ Levaditi 及ビ Yamanouchi $=ョ ッ テ$ 始メテ記載サレタ現象 ヨ考慮ニ入レテ.著者等八肝瀻 $コ$ 加へタ場合卜 加へナイ場合, 溶液人作用 7 比較試驗シタ。

更二 Levaditi ノ所謂假定的ナ Trypanotoxyl 〉形成が訮荿ノミニョッテ促サレルノカ或八 他ノ臟器ニョッテモ亦促サレルカノ問題二關 シテハ文獻上ノ報告ハ一致シテ居ナイカラ海

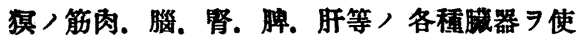
用ンテ同樣ノ試臨シ行ッタ。其結果 Atoxyl 溶液ノミヨ使用ンタ場合ョリ著ンク多量ノ磍 
素が病原體ニヨッテ結合をラレタ。Spir・八脂 エキス」习加へタ時最モ多》Atoxyl ᄏ結合 スルガ Tryp. デ八肝瞞エキス」习用とタ時が 最大デアル。斯ノ如クSpir. 及ビ Tryp. 入試

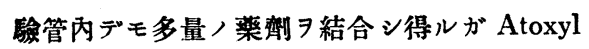
肝䐟エキス」中二浮游七ラレタ Tryp. ヨ除1 テ八何レノ試驗管內二於テモ感染力ニ八變化 ヘナイ。コノコトカラ Parasit が化學治療劑 ヨトルコトトソノ特殊作用ト 八同一デナイト イフコトガワカル。

此問題 7 更二境明スルタメ體内二於テモ何 等特殊作用ノナ1 䒚劑, Verankerung $ᄏ$ 檢 查シタ。郎千再蹛熱二八Atoxyl $尹$ Nagana ニ八 Solganal ヨェランダ。 Solganal ハ Tryp. ニョッテ Spir. ト同樣結合セラレルが Atoxyl 、Spir. ニョッテ結合セラレル最入 Tryp.， 時ヨリモ少イ。

前迅，分析的所見二基イテ化學療法，治瘾 過程 7 更二詳シク區別シテ見ルト明ニ $3 ッ$, Phase ガ區別セラレル。（1）物理化學的過程 ニョッテ化學菜即が Parasitenzelle 二吸著七 ラレル。（2）吸著セラレタ, nativ／化學治療 即が病原體，生活現象ニョッテ賽際二作用ス ル物質二變化セラレル。（3）宿主體／免疫力 ニョッテ治應過程が完成セラレル。

第一，Phase 八微生物が適當ナ物筫二 解レルヤ否ヤ現レル。第二，Phase 八特殊 二作用スル物筫ニ於テノミ證明セラレル。此 Phase 、Parasit / 完全ナ新陳代謝卜關係ス ルコトガコノコトカラワカル。試駼管內デハ 大抵，藥劑，作用ノナイノ八明二麻醉ニョル ノデアッテ病原體八試驗管內ノ試驗トイフ條 件ノ下デハ死ンデキルノデアル。コノヤウナ 假定ニョレバ vitro 作用卜 vivo 作用卜間 ノ不一致, 事賽 ヨ境明スルニ樂デアル。最近 發表サレタ Wagner / 觀察モコレカラ容易二 解釋出來儿。

カ、ル假欺、1912 年 Rothermundt 及ビ Dale =ョッテ始メチ骤表サレッ，後類似，
假境八 Moldovan, James ソ,他學者ニョッ テ唱ヘラレタ。

本來ノ毒素ノ性筫 $习$ 鿁明スルタメニ八更二 研究 $コ$ 要スル。(工藤)

\section{趽験的二得久 Arzneifest J再 歸熱スピロヘータ」ノ性賈}

V. Fischl und E. Singer. Z. Hyg.

116. Bd. 2. Heft. 1934.

實驗的 Arzneifestigung 二關シテ從來知ラ レティル研究，大部分、Trypanosoma テ

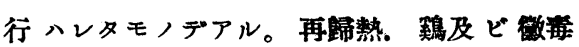
Spirochäta $\Rightarrow$ fest ニシャウト研究者が努力 シタガ殆ンド無䮎二又入全ク徒勞ニ終ッテキ タ。然ル $=$ Feldt ガ始メテ Spirochäta $\exists$ fest ニスルコトニ成功シタト報告シタが詳シイ分 析八行ッテキナイ。

從來交獻上デ知ラレテキル resistent， Trypanosoma 株ヨ得ルタメノ4ッノ方法師子 prophylaktische, kurative, Rezidive-及ビ Reagenzglastechnik，中第二ニアゲラレタ方法 が Spir. ニ於テモ最モ使用二適スル。

歐洲再蹛熱病原 Spir. $\Rightarrow$ Sulfoharnstoff 或 、Solganal 二對シテ fest ニスルコトが出來 タ。コノ株ハ panfest デアル。邲子金化合物 ニョッテモ Neosalvarsan 或八 Rhodium 及 ピ Osmium 監ニョッテモ影響セラレナイ。 fest ニセラレタ株入樂剂二對スル非感受性〉

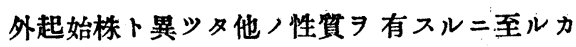
否カヨ檢查シタが雨株八同一ダツタ．郎チ Elektrophorese 試驗デ決定セラレル Ladungs$\operatorname{sinn}$ 二關シテモ中樞神經系ニトッマラナイト イフコトニ關シテモ全ク同一ダッタ。生物學 的性狀 $尹$ 決定 $シ タ$ 後化學藥㖕，作用機序二 關スル研究二進ンダ。砒素及ビ金ノ定量的 测定 ニ八 colorimetrisch 及ビ spektrographisch 八方法ニヨッタ。感染マウス」ヨ金製 制或八 Neosalvarsan デ處置シタ後二此株人 Spir. $\Rightarrow$ 分析的二測定スルト病原顝內二八金 
站二砒素八證明セラレナイ。之二反シ起始株 ，Spir. 八是等，化學藥劑卜著シク多量二結 合スル。

特殊藥㓻，作用機序二關シテ前報二於ヶル 系統的檢查二基イタ見解 ニョレバ. 賽驗的 Arzneifestigkeit $\ni$ 說明スル 性が考へラレル。師手寄生體が毒二次第二慣 レルノ八體表面ノ變化ニョルノカ又八新陳代 謝ノ變化ニヨルノテデアル。第一，場合二於テ 八化學治療剈ハソノマ、トシテハ verankern セラレナイ。第二ノ場合二八恐ラク verankern セラレルが最早有效物質二變化をラレナ1。

著者等, 試驗, 結果カラ明ナ如ク Arzneifestigkeit 二對シテハ第一ノ過程が圭役ヨ演 ズル。系統的二毒二慣ラスト病原體，表面 變化スルタメアル物筫八最早 verankern スル コトが出來ナイ。カクテ Arzneiresistenz 、 治㙩作用 八本來, 機序郎チ本來, 藥劑が有毒 ナ誘導體二變化スルコトトハ最早關係がナク ナル。(工藤)

\section{少量ノ一酸化炭素ノ長期二互 ル作用二關スル血清學的檢查}

P. Hofmann. Z. Hyg. 116. Bd. 2. Heft. 1934.

一酸化宸素, 慢性中毒, 有無, 問題 7 明白 ニスルタメー酸化岸素, 影響, 下ニオイタ試 驗動物/免疫二關スル多樣 研究が行ハレテ キルが是等ノ試驗ノ結果ハ一致シテキナイ。

著者八一酸化孷素 〉衛生學的研究 7 數年來 行ッテキルノデ此範圍內デ血清學的檢查 ッテ最モ注目スベキ.結果ヨ得タカラ次二簡單 二報告スル。

試騟動物トシテハ家鬼及ピ 大ヨ用中每日 6 時間ヅッ土曜日二八 3 時間適當ナ檻ノ中デー 酸化岸素ニフレサセタ。此時間外及ビ日曜日 祭日二八動物入小屋ニオイタ。

使用シタ一酸化崖素人量八 $0.01 \%$ ０.03 \%. $0.09 \%$ 等デカ・ルコト $33 / 4$ 年間續イテヤ ッテッノ一般狀熊。低張食監水二對スル赤血
球ノ抵抗力. Alexin 含有量及ビ溶血性補體， 含有量二對スル影響 夕。

家兔二於テ八試驗，全經過中一般狀態，變 化ハナカッタガ犬二於テハ $0.05 \%$ 人一酸化宸 素ヨ吸入サセルト最初/數日八明二障碍が起

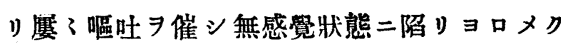
ヤウニナル。然シ試驗ヨ續ケテキル間二是等 八現象八消失シタ。

低張食監水二對スル赤血球ノ抵抗力 $シ$ 檢シ タガ大及ビ家兔二於テ何等變化ハナカッタ。

血清, Alexin 含有量 檢シタが大及ビ家 兔二於テ何等，影響ヨモ受ケナカッタ。

血清/溶血性補體含有量八始又, 4 週間八 試驗前ヨリモ 75-100\%上昇スルガりノ後八 殆ンド此ノ高サニトい゙マッテキル。

一酸化炭素ヨ長ク繼續シテ吸入サセテ其影 劉习檢シテモ正常/防蕃體/形成八障碍セラ レナイ。

現在有力ナ說 $ニ ヨ$ レ゙ー酸化孷素等ハ血液 ノ血色素卜結合シテ酸素ヨ押シノケ從ツテ我 我八酸素供給, 機序二障碍 $习$ 及ボストイフ唯 一, 反應习除イテハ生理的二全ク無關係デア ル。勿論アル學者八䇪息作用/外一酸化宸素 八組糡二及ボス直接作用モ認メラレルトイフ 見解ヨモッテキル。然シ多》, 研究ノ結果否 定セラレタ。一酸化岸素, 慢性中毒, 有無, 問題二關シテハ多クノ人が努力シタが今日迄 ，所血色素／外，細胞成分二對シテモ特殊， 毒作用ヨ及ボスコトヨ賽驗的二登明スルコト 八失敗ニ終ッテキル。著者〉試驗モ亦赤血球 八抵抗性及ビ 正常防街素ノ形成二就テハ一酸 化宸素ヨ長 $ク$ 繼續シテ 供給シテモ全り無關係 デアルコトヨ示シテキル。（工藤）

Methylene-blue 及ヒ Proflavine

J photodynamic action =

ヨッテ非働性ニセラレタ狂 犬病固定毒 J抗元価値

A. Galloway. Brit. J. of Exp. Path. 
Vol. XV. No. 2.

Pedrau 及 $ヒ$ Todd 、 methylene-blue , photodynamic action 二對スルアル bacteriophage 八感受性二關スル Clifton ノ觀察 認シ且敷衍シタ。彼等ハ或ル動物性病毒八此 ノ色素ノアル處デ八可視性光線ノ放射二非常 二感シ易イトイフコトヨ示シタ。distemper virus 八斯入如》非働性ニセラレタ後ニモソ , 抗元性 保有シ效力ノアル vaccine トシテ 使用シ得ルトイフ事實カラ此現象二新シイ興 味が喚起セラレタ。 methylene-blue 及ビ他 色素, 狂大病毒二及ボス photodynamic action 习.研究シ斯ノ如ク非働性二セラレタ病毒八抗 元トシテ，價傎习有スルヤ否ヤヨ決定セント シタ。

本試驗二使用シタ固定毒、Pasteur 研究所 ノ病毒デアッテ.滤過シナイ浮游液. collodion membrane filtrate 及ビ sand and paper pulp filtrateトヨ用キタ。

症大病，固定毒八 methylene-blue， photodynamic action 二對シ感 $シ ゙$ 易1。 collodion membrane filtrate $入$ sand and paper pulp filtrate 中デハ非働性ニセラレルガ洫過シナイ 病毒浮游液中デハ非働性ニセラレナイ。

病毒, proflavine, photodynamic action ニ對シテハ methyleneblue ノソレニ對シテョ リモ比較的感沙易イ。少》トモ生理的二 activ ナ細胞又八感染動物ノ細胞ノアル場合二於テ サウデアル。新二感染シタ滕ノ滤過シナイ病 毒浮游液二對シテ proflavine $ヨ$ 用キタ場合デ モ病毒八非働性ニセラレタ。

methylene-blue 又八 proflavine photodynamic =非働性ニセラレタ狂犬病毒八 其抗元力 $\exists$ 保有スルヤ否ヤヨ檢スルタメ. 先 $\boldsymbol{\Psi}$ sand and paper pulp filtrate $ト$ methyleneblue 又八 proflavine トノ混液ヨ非働性ニシテ 之ヨ家兔, 筋肉內二注射シタ。ソノ後生病毒 习筋肉內二注射スルコトニョッテ試驗シタが 31 頭，家兔，中 26 頭八生キ延ビ 5 頭入狂犬 病デ死ンダ。從ッテ生存率、 $84 \%$ デアル。之
二反シ生病毒 7 筋肉內二接種シタ 16 頭/對 照家兔中 15 頭八狂犬病デ斃レ1頭ノミ生キ 延ビタ。郎チソノ生存率八 $6 \%$ デル。故二 抗元力 7 保有スルコトガ明デアル。

是等ノ動物ノ中ノアルモノニ後二固定毒， sand and paper pulpe filtrate (S. P. F.) 7 撙 內二注射シタがスベテ狂犬病デ嫳レタ。又非 働性病毒, 少量 $ᄏ$ 腦內二接種シタ家鬼八後二 S. P. F. F筋肉內二注射スルト何レモ狂大病 デ䌘レタ。

生病毒 $习$ 使用セズニ neurotropic virus = 對スル免疫ヨ得ルコトハイカ二困難デアルカ トイフコトがワカル。侗中樞神經系，免疫八 生病毒が中樞神經系二達シナイ限》入效力 生ジナイトハ多ク八人ノ見解デアル。モシュ レが真ナラバ以前二非働性病毒 7 注射シタ家

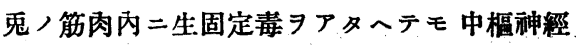
系ニハ達シナカッタヤウ二思ハレル。ソノ理

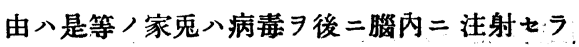
レタ場合二免疫ニナッテキナカッタカラデア ル。（工藤）

\section{パラチフス屬ノ細菌ノ 椟異試験}

H. Habs und L. Seitz. Z. Hyg. 116.

Bd. 2. Heft. 1934.

本試驗入 Paratyphusgruppe , 細菌ニ於テ ハ $1 ッ$ ソ Typ カラ他, Typ 二移行シタト思 ハレルヤウナ血清學的棈造，變化が 試驗管內 デ得ラレルカ否カトイフコトヨ起點トスル。

試驗八順序八他ノ研究者が肺焱隻球菌型 變化 スルコトニ成功 シタ所ノ順序ニナラッ タ。先头正常, Glatt-(S-) Form カラ Rauh, (R-) Form 7 得ントシタ。此際肺炎隻球菌, 特殊 Antigen ニナ.ッッ Paratyphus 菌， somatisches (O-) Antigen, ミョ用キタ。 Geissel-(H-) Antigen ハ之二反り R-Form $\Rightarrow$ 作ルニン關係がナイ。故=0-Antigen，ミ

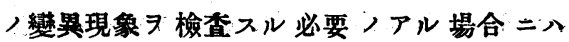


H-Antigen ノナイ所，Paratyphusgruppe， 蜫毛ヨ有シナイ菌株カラ先ヅ出發スルノが最 モ適當デアルト思つ。鞭毛习有シナイ菌株, $\mathrm{S}$-型カラ R-型ヨ得ルトイフ最初, 問題、 BGruppe ， O-Antiserum $\exists$ 加へタ Bouillon ヨ1回經渦スルコトニヨッテ容易二成功シ タ。2 代通過後八既二議論ノナイR型が出來 ル。コレ八本板カラ本板へトイクラ移植シテ 行ッテモ $\mathrm{S}$ 型ヨ生ジナ1。液體培養ニ於テモ 亦此 $\mathrm{R}$ 型ハ少シモ變化シナ1。

此菌株 heterolog，S型二變化サセル圭 試駼 $ヨ$ Dawson und $\mathrm{Sia} /$ 試驗ニナラッテ行 ッタ。郎 0.5cc， Bonillon 卜他, O-Antigengruppe, 死菌，濃厚浮游液(後デ八 Vaccine $ト ヨ$ ンデキル)，等量トヨ加へソレニ RStamm カラ得ラレタ Antiserum , 0.1 c.a. 加へタ。雜菌試驗後此試驗管= R-Stamm, 24 時間 Bonillon 培養, $10^{-7}$, 稀释,モ, 1 滴习加ヘル。試驗管が乾燥スル迄鲜卵器， 溫度二眝へテオキ一定，間隔ヨオイテ寒天本 板二移植シタ。前ノ試駼デハVaccine トシテ $56^{\circ} \mathrm{C} 1$ 時間加熱シテ殺シタ Bact. paratyphi A, C (suipestifer) 及ビ Gärtner /浮游液 培養基ニ加へタ。對照トシテハ何モ加へナ 1 Bouillon $\exists$ 用キタ。移植八 2 日, 間隔 オイテ寒天本板二行ヒソノ上二於ヶル集落 ， Typ 八集落，形，肉眼的態度，外血声學 的檢查ニヨッテ決定セラレタ。此試驗カラ ワカルコト八對照試驗管カラ八培養基ノ乾燥 スルニ至ルマデ移植シテモ常 養七ラレタコトデアル。使用七ラレタ Rauhstamm八極メテ konstant デ他ノ集落型 7 自然 二生ズル傾向ハ少シモナカッタ。之二反シテ 6 本/試駼管中 5 本力ラ $\mathrm{S}$ 型が得ラレタ。コ ， $\mathrm{S}$ 型八第 7 日第 13 日卜，間二於テ始メテ 現レリノ後八試驗,終ル迄登明七ラレタ。從 ッテ Vaccine.中二培養スルトR型カラ $\mathrm{S}$ 型二 逥元スルコトが可能デアル。其後ノ多數入試 驗が示ス如ク此還元八非常二規則正シク成功 シテキル。 homolog，Vaccine $ヨ$ 加へタ場合
デモ成功スル。 S-Stamm ヨ殺スニ八 $100^{\circ} \mathrm{C}$ 二加熱シテモ1、Vaccine $\exists$ 加へズニ AntiR-Serum 型ヨ得ルコトが出來ナイ。

斯〉如クニシテ得ラレタ Glattstämme 八起 始株卜八培養上同一デアルノミナラズ詳細， 血清學的檢查 二於テ泣二起始株卜モ同一，態度

著者等, 試驗 カラ次ノコトが推論セラレ ル。'stabil ト思ハレルR型 7 homolog 或八 heterolog, Paratyphus 菌, 殺シタ浮游液 中二培養スルコトニョッテ $\mathrm{R}$ 型カラ $\mathrm{S}$ 型 7 作 ルコトガ容易二出來ル。 $\mathrm{R}$ 型カラ $\mathrm{S}$ 型二變化 スル際ニ八常 $=$ homolog, 型二カール。他 ノ $\mathrm{S}$ 型ニ移スコトニ八未ダ成功シテキナイ。

$\mathrm{R}$ 型カラ $\mathrm{S}$ 型 7 得ヨウトシタ 試驗二於テ期 待シナカッタ Nebenbefund が得ラレタ。郎 于6本，試驗管中 4 本二於テ變種が現ハレ タ。コレ八集落, 形ニョレバ Paratyphus 菌 二特有ナ粘液型卜圭張セラレルモノダツタ。 粘液型ノ現レタノ八上記ノ試驗デハ一部 $\mathrm{S}$ 型 ノ現ハレル前ダッタ。粘液型, 發生が $\mathrm{S}$ 型, 發生卜無關係デアルコトハ或ル試驗管二於テ 八 $\mathrm{R}$ 型！外 $\mathrm{S}$ 型ノミが現レテキルコトカラワ カル。

カ、ル粘液型ハソノ後ノ試驗二於テ鞭毛 有スル菌株カラモ得ラレタ。Bakteriophage 八作用八粘液型, 發生ニ八必要デナイヤウニ 思ハレル。(工藤)

\section{腸チフス」ノ豫防接種及ビ 免疫ニ閵シテ「チフス菌ノ $\mathrm{S}$ 型及ビ $\mathrm{R}$ 型ノ研究}

Maltaner, F., Journ. Immunol. Vol.

XXVI, No. 3. p. 161-192. (1934).

「チフス菌， R型八豫防 vaccine $ヨ$ 作ルニ 八稌り㑯值が無イト言ハレテキル。然シ古イ 保存培餈が自然二發生スルR型まナル根源

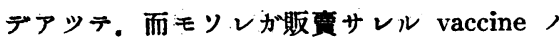
整造二最も多ク用ヒラ゙レテキルコトヨ考へル 
トキハ $\mathrm{S}$ 及ビ $\mathrm{R}$ 株，像防的瑻值 ト八實際上意義アルコトデアラウ。賽驗小動 物二於テ八人體二於ヶルト同樣，腸チフス症 狀ヨ起サシメルコト入殆ド不可能デアルカ ラ.之マデニナサレタ多》，報告入決定的， モノト八言飞難1。但家鬼二於テハ一定〉菌 血症 ヨ起サシメ. 又多ク/點二於テ人體二於 ケルト似タ症狀习起サシメ得ルヨ以テ著者八 賽驗動物トシテ家兔习用七.且ッ「チフス菌ノ 或株 又菌, 戀型株, 作用及ビ $\mathrm{S}$ 型. $\mathrm{R}$ 型 /豫防的 價值ヨ知ラウトシタ。

先ッテフス菌ノ變型（dissociation）二就テ 賽驗シタが普通ブイオン」. $0.1 \%$ 石炭酸加 ブイオン及ビ $1 \%$ 葡萄糖加ブイオン培養力 ラノ本板培養二於テ定型的 $\mathrm{R}$ 型がミラレタ が是等二於テハ $\mathrm{R}$ 型ヨ永ク保タシメルコト

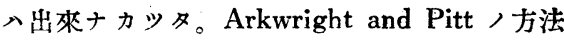
$=\Xi ル 卜$ 數株力ラ 1 ケ月以內二永久的 $\mathrm{R}$ 型 $\ni$ 得ルコトが出來タ。定型的 $\mathrm{S}$ 型 $コ$ 得ルニへ $\mathrm{pH}$ 7.4-7.6，普通ブイオン」二數時間培養シタ ル後. 本板ニ移シテ 16-18 時間，培養二於テ 最モ $\mathrm{S}$ 型习示ス集落ヨ探リ。之ヨ又「ブイオ ン」ニ移植スル。斯ク，如キコトラ反復スルコ トニョリ $\mathrm{S}$ 型ヨ保タシムルコトが出來タ。而 シテ鞭毛，有ル株カラモ。無侏カラモS及 $\mathbf{R}$ 型ヨ得ルコトが出來タ。然シナがラ夫等， 細菌ノ大サ八株ニョリ夫々少シッ゙ッ異ツテキ タ。外膜 (capsule) 八總デ株ニミラレタが䩒 毛卜異りり/染色法八困難デアル。Jonston and Mack /方法が最モ良イ。而シテ鞭毛八 原形質カラトイフョリハ鼻口外膜カラ出テキ ル樣ニミェル。Sanarelli，方法 ヨ用ヒテR型 $\exists \mathrm{S}$ 型二杘サウトシタが完全ニハ成功シナカ ッタ。

是等, 株, 免學的關係八雲絮狀㠜集反應 八䩡毛ヨ有スル S 及 $\mathrm{R}$ 型ニ於テミラレ.ソノ 程度八雨型二於テ同ジデッタ。而シテ同程 度, 交冬凝集反憵モ。雲絮狀凝集素/完全ナ ル吸收モミラレタ。顆粒狀凝集反應へ總テ，
免疫血清二於テミラレタが $\mathrm{S}$ 型ヨ以テ作ラレ タルモノ二於テ著シカッタ。而シテ交文㠜集 反應モ。顆粒狀凝集素, 交丑吸收モ雨型二於 テ餘り著ンク八起ラナカッタ。

$\mathrm{R}$ 型/鞭毛,有ルモ，及ビ無イモノ，雨株 二於テ $\mathrm{R}$ 型內質性免疫血清 (rough somatie antisera）二對シテヨク凝集シナイもノがアッ タが是等ノ菌 $790-95^{\circ} \mathrm{C}$. 1 時間加熱シテ凝 集反隹习試ミタト・ロ 1:400迄凝集シタ。・ レデ結論的デハナイガ， $\mathrm{R}$ 型ニ於デ所罰 somatic agglutinogen 八原形筫結合シ。 $\mathrm{S}$ 型二於テへcapsule 或入鞭毛ノ何レカ或ハッ 八兩方卜結合シテキルもノト思ハレル。佾保 存培養二於テ試驗シタガ生活菌 ヨ以テ試驗ス ルトキハ純粹ノ $\mathrm{S}$ 型デアッテ。加熱後試驗ス ルト一部R型ヨ示ス株がアッタ。而シテ是等 八培養上八中間型ノ性狀 毛习有スル $\mathrm{R}$ 型株デ生活菌デ、 R及 $\mathrm{S}$ 型, somatic antiserum 二對シテ凝集シナイが.加 蕉スルト．スベテノ $\mathrm{R}$ 型血清二凝集シタモ，

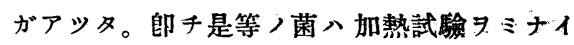
トキハ誤テ分類サレルカモシレナイ。生活菌 デハ凝集シナイトイフコトハ培養上ノ性狀卜 血清學的性狀卜 八間二數多, 矛盾 $ᄏ$ 起又理由 トナルデアラウ。殊二鞭毛习有スルモノ或八 capsule ヨ有スルモノニ於テ然ルデアラウ。

$\mathrm{R}$ 型及ビ $\mathrm{S}$ 型， virulence 及ビ toxicity $\Rightarrow$ 比較スルタメ = Gay and Claypole $=ヨ ッ テ$ 記载サレタ保菌狀態 $习$ 生ゼシメル方法 $习$ 用七 タ。之ニョルト侵入力 (invasive power) 八專 ラ S 型二存シ. toxicity 八雨型ニホボ同等二 存スル咏デアル。

家鬼二保菌狀態 防接種/價做 ヨ比較シタガ. $\mathrm{S}$ 型 $コ$ 以テ接種 サレタル家鬼ノ血清へ $\mathrm{R}$ 型ヨ以テ接種サンタ ル血清ヨコモ高度ノ凝集價习示スが、防綮力 (protective agent)八 $\mathrm{R}$ 型 vaccine 八方办優 ツテキルコトガ制ツタ。郎チS 型菌つミンラ

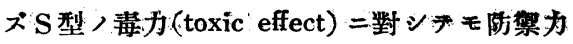
タ、示ンタ。 
$\mathrm{R}$ 型菌カヨ作ラレタ vaccine $ヨ$ 以テ免疫サ レタ家兔/血清が $\mathrm{S}$ 型菌ヨ凝集シナイトイフ コ卜入血清學的作用卜能動性免疫性ノ發生卜 ノ間二八相關關係が無イトイフコトヨ示ス。 之八Gay ソノ他ノ人々ニョッテ反復指摘サ レテキルコトデアル。

著者入上記,實驗ヨリ防徱力二八白血球 作用郎チ喰菌反㗹が關係シテナルコトヨ重視 シテ・健常及ビ免疫家兔ニ「チフス菌ノ生菌 ヨ靜脈內注射シテ白血球, 反應 $\exists$ 觀タ。尚健 常及免疫海堔, 腹腔內注射モシテ同樣ノ觀察 ヨシタ。 $\mathbf{R}$ 型菌 7 健常家鬼, 静脈內二注射ス ルトS 型菌ヨ注射シタトキョリモ著シイ leucocytosis が起り之が續ク。 $\mathrm{S}$ 或ハ $\mathrm{R}$ 型菌 7 以 テ豫メ免疫サレタル家兔 $=\mathrm{S}$ 生菌 $\ni$ 射スト初 メ leucopenia ガ起り續イテ hyperleucocytosis ガ起ル。然ル二健常家兔二於テハ反應輕度デ アッタ。R及 $\mathrm{S}$ 八生菌 7 海獏, 腹腔內二注射 スルト $\mathrm{S}$ 型ハ $\mathrm{R}$ 型ョリモ毒性が强カッタ。注 射サレタ $\mathrm{S}$ 型菌八腹腔內二テ速二增加スルが $\mathrm{R}$ 型入喰菌作用ニョリ忽チ處理サレテシマッ タ。郎チ $\mathrm{R}$ 型菌ハ $\mathrm{S}$ 型菌ヨリモ旺盛二喰菌サ レタ。

此ノ結果 Э觀レバ嗆菌作用八特異性體液反 憵ヨリモ防禦作用二對シテ重要ナル因子ヨナ シテキルコトガ制ル。勿論體液反應が喰菌作 用ヨ補助スル役目 7 演ジテヘキルが。(中込)

\section{含水炭素二對スル抗體ノ問題} (第 2 報)

Uhlenhuth, P. und Remy, E., Zeitschr. f. Immunitätsforsch. u. experim. Therapie, 82. Bd.. Heft 3, S. 29-241. (1934).

含水炭素二對スル 抗體産生二就テ. 著者等 ハ更二六炭糖ノ形タナシ全ク堂素习含有シナ イ含水宸素 射用, 純㑘萄糖 $\left(\mathrm{C}_{6} \mathrm{H}_{12} \mathrm{O}_{6}\right) \rightarrow$ Gummi arabicum 及ビ Olivenöl $\ni$ 以テ作ッタ乳臍中二溶解シ。 之ヨ少量ョリ漸堵シテ家鬼, 觧脈或八腹谐內
二. 一定ノ間隔 7 以テ 64 日 =互ッテ注射シ蒲 萄糖, 全量 $73.12 \mathrm{~g}$ トナス。他二葡萄糖 Kollodium' '以テ被覆シ.之 reibung ノ形デ用ヒタ。斯ク處置シタル家兔 , 血清二就イテ沈降反㗂. 補體結合反礁等 7 觀タが總テ陰性デアッタ。

葡萄糖分子二案素，入ッタ Glukosamin $\left(\mathrm{C}_{6} \mathrm{H}_{11} \mathrm{O}_{5} \mathrm{NH}_{2}\right)$ ヨ以テシテモ䊅果ハ㓌性デア ツタ。

ソレデ著者等八空素习含有スル低級分子， 含水炭素. 就中Glukosid ガ抗元タリ得ルカ否 カヨ實驗シタ。之二、Amygdarin $\left(\mathrm{C}_{19} \mathrm{H}_{27} \mathrm{O}_{11}\right.$ $\mathrm{CN})$ 及ビ Cathartin酸 $\left(\mathrm{C}_{30} \mathrm{H}_{35} \mathrm{NO}_{5}\right)$ ヨ用ヒタ。 此際溶液 $1 \mathrm{c} . \mathrm{c}$. 二就キ窒素が $0.300 \mathrm{mg}$ 含有ス ル樣ニシ。 64 日二互リ。家兔 1 頭二就キ全量 Glukosamin 、0.234g, Amygdarin $>0.520$ $\mathrm{g}$, Cathartin 酸八 $0.572 \mathrm{~g}$ 二達スルダケ注射 シタ。更二是等ノ物質 Aluminiumhydroxyd 二吸著七シメ之 7 畺空 テ乾燥シ. Olivenöl $\ni$ 以テ乳劑トナシテ家兔 二射シテ實驗シタが總テ陰性二絡ツタ。郎チ 是等低級分子化合物八抗體產生不可能すり卜 結論サレル。

窒素含有，Glukosid が抗元タク得ルニ八 高級分子化合物デ特別ナル構造 液トナストキ定型的, 膠質性 7 有シテキルコ トが必要デアラウ。斯クシテ Ford ハ Amantia phalloides, Pilzgift 二於テ. Acree und Syme 八 Rhus toxicodendron $\ni$ 以テ抗體産 生二成功シタノデアル。

次二著者等、 Gummi arabicum 中ニアル 抗體産生要素 $习$ 探究セントシテ之 7 强》罯元 セシメタル物質习用ヒタ。Gummi arabicum 八單一ノモノデ無イコトハ諸家ニョッテ知ラ レテキル。又販冨サレテキル Arabin 或八 Arabin 酸モ哇素 7 含有シテキル。Tschirch 八 此，窒素含有物質 $习$ 定量的ニ取り離スコトハ 不可能ダトシタ。Gummi arabicum 中ニアル 窒素部分 abbauen スルタメ二著者等ハ先ッ゙ Avery-Heiderberger ノ方法ニ準ジ。侗種々ナ 
ル處置 ヨ加へタ。之 $7 \mathrm{P}_{1}$ 卜名付ケ. $\mathrm{P}_{1}$ 更 二種々處理シテ窒素 7 除去シ. 之 $7 \mathrm{P}_{2}$ ト稱シ

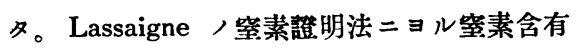
量八市販, Gummi arab. ニ於テH. $\mathrm{P}_{1}$ 及ビ $\mathbf{P}_{2}=$ 於テ各十デアッタ。蛋白反應八Millon 八反應ダケが Gummi arab. 及ビ $\mathrm{P}_{1}=$ 於テ陽 性他, 諸反應入總テ㓌性デアッタ。此, $\mathrm{P}_{2}$ 溶 液 $习$ 以テ Gummi arab.免疫血清二對シテ沈降 反隹习試ミタガ㓌性デアッタ。又 $\mathrm{P}_{2}$ フ以テ家 鬼二抗體 7 産生セシメントシタガ之モ㓌性二 終ツタ。同汸方法ニョリ Gummi arab. デ入 產生セシメ得タ。此實驗ニョリ Gummi arab. 窒素ハ 2 ッノ形デ存在スルコトヨ知ル。郎 チ 1 ツ八抗體 7 産生セシメ得. 高級分子ノ蛋 白體ノ形ヨナシ。他八Glukosid ，窒素含有 化合物 ノ形 $コ$ ンテキル。而シテ Gummi arab. 八抗體產生能八專ラ蛋白體形二起因シテ キルノデアル。何トナレパ Gummi arab. , 窂素部分 $\ni$ abbauen スルト抗元性ヨ有シナ イ含窒素物 7 得ルコトが出事ルカラ。Gummi arab. 中ニアル 含水炭素部分二大ナル變化 $\ni$ 起スコトナシニソ, 窒素 ヤ否ヤ八疑問ダ。又本實驗が空素八唯中間, 役割ヨ演ズルトコロ，含水炭素抗體反應二關 シテキルトノ見解ハ正シク無イデアラウ。郎 チ Heiderberger-Avery 等，見出シタル多糖 類抗體產生二於テモ Gummi arab. ヨ以テ, 著者等，實驗卜同樣二他，Verhälțniss が存 在シテキルデアラウ。彼等ノ報告ニョレバ彼等 ニョッテ細菌ヨリ得ラレタル多糖類、Gummi arab. ，含水炭素二近イモノダトサレテハキ ルガ。

著者等八上記 八見解及ビ Gummi arab. 八峷 素部分, 生物學的特異性 7 登セントシテAnaphylaxie 試驗 ナナシタ。郎キ豫メ Gummi arab. 免疫血清 $ᄏ$ 射シタ海慣二 Gummi arab. 溶液ヨ射シタガ總テ定型的， anaphylak. Schock ヨ起シタ。又 Gummi arab. 溶液 豫メ射シテォイテ後二同シ溶液 anaphylak. Schock ヨ起シタ。對照動物入何
等異狀入無カッタ。

Zozoya ヘ Kollodium デ被覆シタル Dextran $\left(\mathrm{C}_{6} \mathrm{H}_{10} \mathrm{O}_{5}\right) n$ ７以テ純粹，含水宸素樣抗體 7 産生七シメ得及。其, 他各種, 細菌, 多糖類 ヨ以テモ成シ得タガ. 是等細菌ノ多糖類八總 テ跮素ヨ含有シテキタコトヨ注意シナケレバ ナラヌ。然シナガラ今後實際二無窒素物 7 以 テ抗體が産生シ得ラル、コトが確メラル、ナ ラバ. 含水炭素/抗元性入先ヅ第一ニソノ分 子ノ大小が問題トナリ. 更二又血清蛋白體二 對スレ彼等, 化學的關係モ決定的役割 $ᄏ$ 演 $シ$ ナケレバナラヌトイフ事實が確メラレルデア ラウ。(中込)

\section{結核菌二對 スル殺菌效力試驗}

Chon, M. L., Journ. Bacteriol., Vol.

XXVII, No. 5, p. 517-526(1934).

結核菌二對スル消毒劑ノ效力試驗モ現今八 往時ョリモ正磪ナル方法が行ハレル樣ニナッ タ。殊二最近化學療法及ビ培養法等二興味が 注がレル樣ニナツテカラ著シキ進步 7 示シ タ。Wells ソノ他ノ人々ニョツテ.速二發市ス ル細菌二對スル殺菌係數ノ決定法 7 結核菌 隹用セント試ミラレ. Rideal Walker法及ビ ソ, 變法. 衞生研究所法. 最近ニ八 Reddish , 方法等が行ハレルが、結核菌二對シテハ何一 定セル方法人報告が無イ。結核菌ニ對シテハ 速二發去七シメル適當ナ液狀培養基が無イ コトが一般法 $ヨ$ 行フコトノ出來ナイ原因デア ル。又大量,菌二對スル效力カラ直二少量 , 菌二對スル效力 $\exists$ 決定スルコトハ不可デア ルガ. 現在毒力高キ人及牛型結核菌 $71 \mathrm{mg}$ （10 億，細菌）以下移植シ テ是等 7 容易二取 充セシメル樣ナ液狀培養基ハナイ。郎チュ， 場合死滅, 規準八數 10 億, 細菌二關シデ ルノデアル。向又體液、組織或八蛋白液等, 存在ノ影響等モ考虑ニ入レル必要がアル。之 迄液狀培地 7 用七テ結核菌二對スル殺菌效力

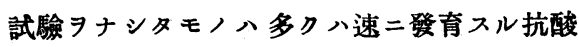
性菌或ハ鳥型菌ヨ以テナサレタ。 
ソレデ著者八大量，菌卜共二少量，菌二對 スル效力. 速二發育スル抗酸性非病原菌デナ ク種々ナル株ノ結核菌 7 使用シ。且\%。蛋白 體. 血液或八他, 同䇐二作用スル物質八混 在等 7 考慮ニ入レテ次, 3 樣, 試驗 $\ni$ 試ミ 及。即 $\neq(1)$ 静止的結核菌殺菌試驗 (tuberculocidal-static test).（2）時間的結核菌殺菌試驗 (tuberculocidal-time test). (3) 體液, 存在 = 於テ>時間的結核菌殺菌試驗 (tuberculocidaltime test in the presence of body fluids) アルガ.（1）八消毒劑习除クノデナク單二稀 釋ヨナス二過ギヌカラ斯ク名付ヶタノデア ル。(2)八殺菌時間 ヨ考虑二入レ. (3)八郎于 溶液中二體液 (本實驗デ入血液) $\ni$ 加入七シ メタモノデアル。ソノ方法 7 簡單二記述ス レバ $(1)$ 二於テハ種々ナル稀釋ノ消毒劑ノ一 定量 $=1 \mathrm{mg}$ 以下/種々ナル結核菌ノ入レ ル浮游液, 同量 $习$ 混和シ 30 分間培養シタル 後食留水デ稀釋シ此一定量 馬鈴薯培地二植エル。此試驗入即千静止的效 カト共二作用スル䒚劑, 適當濃度 . 知ルコト ガ出來ル。（2）八遠心沈溉管二一定量八消毒 劑ヨ入レ之二細菌, 浮游液, 一定量 和液ヨ種々ナル時間培養シタ後. 消毒劑ノ静 止的作用 $コ$ 出來ルダケ除クタメン之ヨ食監水 尹以テ一定量二稀释シ. 此液一定量 7 crystalviolet 馬鉿薯培地二植エル。（3）八大／枸磁 酸加血液, 一定量二凡ソ $1-2$ ケ月培養, 結

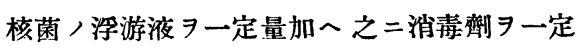
量加へテョク混和シタル後食鹽水ヨ以テ一定 最二稀釋シ後種々ナル時間培養スル。此ノ際 稀釋混和液 $习$ 少量探り之二硫酸 振壍シッ、30 分間培養スル。然ル後之ヨ苛性 曹達 以テ中和シ $\mathrm{pH} 6.8$ トナス。之ヨ遠心 沈揤シ. 食監水 沈澱物 7 crystal-violet馬鈴幕培地及濃厚卵黄 培地二植エル。

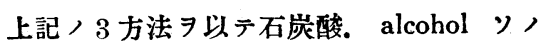
他市販, 多數 八消毒劑二就キ 結核菌殺菌試驗 ヨナシタ。(中込)

\section{癩病照 ヨリノ抗酸性菌}

Salle, A. T., Journ. Infect. Diseas.

Vol. 54, No. 3, p. 347-359 (1934).

1872 年 Hansen が賴患者入組樴二抗酸性菌 八存在スルっトヨ.報告シテ以來. ソ,培䖯が 多數企テラレテキルガ. 真實二成功シタモ， ガアルカハ令侗疑問デアル。

著者八瀬組織二於テ非抗酸性期卜共二抗酸 性期习有スル 1 種, diphtheroid 7 分離シ得 タカラ茹二報告スル。

培養法、Carrel /方法 $ニ ョ ル$ 組織培養法

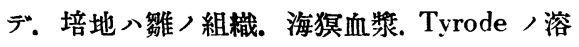
液及稀程七儿雊胎兒液デアッタ。材料八人瀬 ノ結節及ビ鼠, granuloma デアル。

培養結果入破壞サレタル瀬組糡が培養七ラ レタ時ニノミ陽性ヨ示シタ。同一患者力ラ得 タ 2 \%結節及ビ異ル 2 人, 患者カラ得タ 2 ッ八結節カラ同漾二陽性成績 , 浮游液 7 glycerin 馬鈴薯培養基及凝固鴙卵 培地二置キ paraffin $\exists$ 以テ密封シ $37^{\circ} \mathrm{C}=2$ ケ 月保ッタが之二於テハ發育が認メラレナカッ タ。組織培養二於テ陽性 示七ルモ八公埴 七ル雊組糡, 上或ハッ, 近ク二抗酸性桿菌, 稩密ナル集皘ヨミタ。青色 混在シテキタ。他方上部, 胎兒液二八抗酸性 菌八唯偶々存在スルニ過ギヌガ diphtheroid ノ集積ヨ示シタ。之 7 每日觀察スルト抗酸性 菌八次第二消失シテ遂二 diphtheroid, ミト ナッタ。之 7 日目每二新組織培養二移植シ. コ, 後培養ヨリ材料 $习$ 普通培地二移スト青色 , diphtheroid, ミ發育シ。抗酸性菌 コト八出來ナカッタ。郎千彼等八同一菌, 暴 レル期(stage)ノモノデアルト信ゼラレル。組 織培盖 $=20$ 回移植 $\exists$ 續ケタ後. 細ク刻メル雛 胎兒培地二移ス卜 48 時間二テ抗酸性菌/最 良, 發育がミラレ diphtheroid 卜同數程存在 シテキタ。コ>時期以後八抗酸性菌八次第二 消失シテ 7 日目二八殆ド總テ青色菌ノミトナ

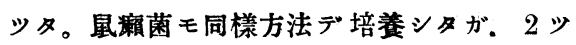


ノ實驗ノ中 1 ッダケ陽性成績 7 得タ。コノ染 色站二培養所見八人癞, 場合卜全ク同樈デア ツタ。

コ, diphtheroid 及ビ抗酸性菌八非常二多 形性デアル。而シテコノ多形性八培養/時期. 培地ノ種類ニョリ著シク變ル。diphtheroid八 單在. 複在. 時ニハ $3-4$ 個ノ短鑚 サナシテ キル。菌體八固形 (solid). 顆粒狀或八珠數樣 (beaded) ヨナシテキル。時二八空胞 $ヨ$ 有シテ ‘夕。或八非常二短ク殆ド coccoid $=ミ エ ル$ が他ノモ, 八非常二長ク細イモノがル。染 色反隹が異ルダケデ抗酸性菌卜 diptheroid卜 , 間二形態上ノ相違ハナ1。同汇形ノモノが 赤ク或八青ク染ツテミェルノデアル。固形， モ)八若1培養二多》．顆粒狀及珠數狀, モ 八ハ古イ培養ニ多ク見ラレル。

人演，培養力ラ， diphtheroid 7 兽通寒天 平板二移植スルト 48 時間, 後菌集落 $コ$ 得ル。 之 $习$ 食監水二浮游セシメ再ビ 平板二培養ス ル。斯》，如キコト 78 回反復シタが. 本板 上= 2 種, 集落郎チ $\mathrm{R} 及 ヒ ゙ ~ \mathrm{~S}$ 型ヨ認メタ。二 , 各集落 $习$ 凝固鶴卵培地二移植 スルト 48 時

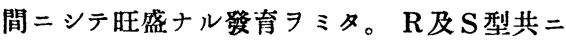
空氣, 存在二於テ八濃イ橙色, 色素 $\exists$ 作以 タ。然シ paraffin デ密封スルトコ，色素八次 第二消失シタ。R型八乾イタ，晹ノアル發育 ７示シ結核菌， $\mathrm{R}$ 型卜似テ.キナイ。 $\mathrm{S}$ 型八濕
ツテ光澤アル發育ヨ示シタ。兩者共䳋卵培地 ニ於テ著ンキ發青ヨ示ス。

鼠及ビ人䝷カラ得タ $\mathrm{R}$ 及ビ $\mathrm{S}$ 型ヨ夫々培養 シテソノ所見 ヨミタが $\mathrm{S}$ 型及 $\mathrm{R}$ 型八各々一定

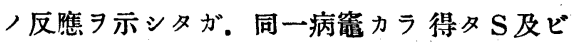
$\mathrm{R}$ 型が各々多少異ル反應习示シタ。郎チ形態 上及ビ培養上同一ナル 2 \%, diphtheroid 菌 が異ル材料カラ分離サレルノデアル。是等， 菌八培地ノ表面二淡紅色, 溥膜 型八顆粒狀入， R 型八薄片狀ノ沈激 $习$ 作以多。 人及鼠瀬力ラ得タ $\mathrm{S}$ 型 diphtheroid，純培養 ᄏ細ク刻ンダ胎兒培地二移植スルト48時間， 終り二於テ抗酸性菌, 集積 二八抗酸性菌、次第二減少シテ遂二多形性， diphtheroidノミトナッタ。之习新シキ培地二 5 -6 日目每二移植スルト同鿊結果 7 得ル。

以上, 實驗 ヨリ嫁菌八組織ニ於テ八抗酸性 ヨ示ン曾通培地二於テ八非抗酸性 $コ$ 示ス。此 染色性八培地, 組織, 生活條件 $=$ ヨ・y變化 ル。郎チ組織が活潑二發青シッ、アルトキハ 强》抗酸性 レバ抗酸性八次第二消失シ組糡 が死隇スル ト. 非抗酸性 diphtheroid 菌ノミトナルコト $\exists$ 知ル。之ョリ著者八人及鼠癩ハ 1 \%, 而 テ同ジ細菌ニョツテ起ルト信ゼラレルト結論 シタ。(中込) 